\title{
Pharmacological treatments inhibiting levodopa-induced dyskinesias in MPTP-lesioned monkeys: brain glutamate biochemical correlates
}

\author{
Nicolas Morin ${ }^{1,2}$ and Thérèse Di Paolo ${ }^{1,2}$ * \\ ${ }^{1}$ Neuroscience Research Unit, Centre de Recherche du CHU de Québec, Quebec City, QC, Canada \\ 2 Faculty of Pharmacy, Laval University, Quebec City, OC, Canada
}

\section{Edited by:}

Antonio Cerasa, Institute of Bioimaging and Molecular Physiology, Italy

\section{Reviewed by:}

Antonio Cerasa, Institute of

Bioimaging and Molecular Physiology, Italy

Barbara Picconi, IRCCS, Italy

\section{*Correspondence:}

Thérèse Di Paolo, Neuroscience Research Unit, Centre de Recherche du CHU de Québec, 2705 Laurier Boulevard, Quebec City, QC GIV 4G2, Canada

e-mail: therese.dipaolo@crchul. ulaval.ca
Anti-glutamatergic drugs can relieve Parkinson's disease (PD) symptoms and decrease 1-3,4-dihydroxyphenylalanine (L-DOPA)-induced dyskinesias (LID). This review reports relevant studies investigating glutamate receptor subtypes in relation to motor complications in PD patients and 1-methyl-4-phenyl-1,2,3,6-tetrahydropyridine (MPTP)-lesioned monkeys. Antagonists of the ionotropic glutamate receptors, such as $\mathrm{N}$-methyl-d-aspartate (NMDA) and $\alpha$-amino-3-hydroxy-5-methyl-4-isoxazolepropionic acid (AMPA) receptors, display antidyskinetic activity in PD patients and animal models such as the MPTP monkey. Metabotropic glutamate 5 (mGlu5) receptor antagonists were shown to reduce the severity of LID in PD patients as well as in already dyskinetic non-human primates and to prevent the development of LID in de novo treatments in non-human primates. An increase in striatal post-synaptic NMDA, AMPA, and mGlu5 receptors is documented in PD patients and MPTP monkeys with LID. This increase can be prevented in MPTP monkeys with the addition of a specific glutamate receptor antagonist to the L-DOPA treatment and also with drugs of various pharmacological specificities suggesting multiple receptor interactions. This is yet to be well documented for presynaptic mGlu4 and mGlu2/3 and offers additional new promising avenues.

Keywords: Parkinson's disease, L-DOPA-induced dyskinesia, motor complications, glutamate receptor, basal ganglia, direct pathway, indirect pathway, receptor interaction

\section{INTRODUCTION}

Parkinson's disease $(\mathrm{PD})$ is the most common neurodegenerative movement disorder and is likely to increase due to the aging population (1). PD is principally attributed to the death of dopamine (DA) neurons in the substantia nigra, but other neurotransmitters, such as glutamate, are also affected (2). There is no cure for PD but symptomatic treatments are available (3). Restoring lost DA with its precursor, L-3,4-dihydroxyphenylalanine (L-DOPA), remains the most effective treatment (4). However, many patients $(\geq 40 \%)$ develop motor complications after $5-10$ years of treatment (5). These motor complications include motor fluctuations

Abbreviations: 6-OHDA, 6-hydroxydopamine; Akt, protein kinase B; AMPA, $\alpha$-amino-3-hydroxy-5-methyl-4-isoxazolepropionic acid; cAMP, cyclic adenosine monophosphate; DA, dopamine; DARPP-32, DA and cAMP-regulated phosphoprotein with molecular weight 32; DHA, docosahexaenoic acid; ERK, extracellularsignal-regulated kinase; GABA, $\gamma$-aminobutyric acid; GSK3, glycogen synthase kinase-3; GP, globus pallidus; GPe, external globus pallidus; GPi, internal globus pallidus; iGlu, ionotropic glutamate; KA, kainate; L-DOPA, levodopa (L-3,4dihydroxyphenylalanine); LID, L-DOPA-induced dyskinesias; MAPK, mitogenactivated protein kinase; mavoglurant, AFQ056; mGlu, metabotropic glutamate; MPEP, 2-methyl-6-(phenylethynyl)pyridine; MPTP, 1-methyl-4-phenyl-1,2,3,6tetrahydropyridine; MTEP, 3-[(2-methyl-1,3-thiazol-4-yl)ethynyl]pyridine; mTor, mammalian target of rapamycin; NAM, negative allosteric modulator; NMDA, $N$ methyl-D-aspartate; PD, Parkinson's disease; PI3K, phosphoinositide 3-kinase; PKA, protein kinase A; PP-1, protein phosphatase-1; STN, subthalamic nucleus; Wnt, wingless/integrated-signaling. and abnormal involuntary movements, such as L-DOPA-induced dyskinesias (LID), and contribute to limit the quality of life in PD patients and can be very difficult to manage (6). Motor fluctuations such as "wearing-off" are also common. Wearing-off is defined as a reduced duration of benefit from an individual LDOPA dose and a recurrence of parkinsonian symptoms before the next normal dose of L-DOPA (7).

No drug is yet available for LID, aside from some benefit with amantadine that has anti-glutamatergic properties (8). Glutamatergic transmission is increased in the basal ganglia in PD (9) and is also believed to be involved in $\operatorname{LID}(10,11)$.

The mechanisms involved in the occurrence of LID are still not fully understood, altered dopaminergic and non-dopaminergic neurotransmission in the basal ganglia are observed in LID (12). A recent strategy is to treat LID with adjunct drugs targeting non-dopaminergic neurotransmitter systems such as glutamate to indirectly modulate basal ganglia DA neurotransmission (13).

Glutamate is involved in many physiological functions through its interactions with ionotropic glutamate (iGlu), ligand-gated channel, and metabotropic G-protein-coupled glutamate (mGlu) receptors. iGlu receptors drugs suppressing glutamate excitatory transmission often create undesirable side effects (14), whereas acting on mGlu receptors could lead to a more subtle and/or circuit-selective modulation of excitatory transmission (15). Pharmacologic characterization of metabotropic glutamate 5 (mGlu5) 
receptors and its selective negative allosteric modulators (NAMs) show therapeutic potential in animal models of PD (16-18) and efficacy in human PD $(19,20)$. While mGlu5 receptors regulate LDOPA-induced motor behavior, the mechanisms involved remains to be fully elucidated (21).

This review focuses on relevant studies investigating glutamate receptor subtypes in the pathophysiology of PD and LID. Brain biochemical correlates of motor complications in PD patients and 1-methyl-4-phenyl-1,2,3,6-tetrahydropyridine (MPTP)-lesioned monkeys are reviewed.

\section{GLUTAMATE NEUROTRANSMISSION IN THE BASAL GANGLIA AND PARKINSON'S DISEASE}

Glutamate is the brain's most abundant excitatory neurotransmitter mediating as much as $70 \%$ of synaptic transmission (22). Amantadine reduces LID, it also improves akinesia, rigidity, and tremor (3). The non-selective inhibitor of glutamate transmission (riluzole) was shown to block L-DOPA-induced motor complications in 6-hydroxydopamine (6-OHDA) lesioned rat model of $\operatorname{PD}(23,24)$ and the glial glutamate transporter GLT1 is increased in dyskinetic L-DOPA-treated 6-OHDA rats $(25,26)$. However, riluzole was not effective in humans to relieve $\operatorname{LID}(27,28)$.

\section{LEVODOPA-INDUCED DYSKINESIAS AND NON-HUMAN PRIMATE MODEL}

L-DOPA-induced dyskinesias are abnormal involuntary movements seen typically at the peak effect of each dose of L-DOPA in PD patients (3). LID can be viewed quantitatively as an excess of movement or qualitatively as a problem in selecting the appropriate motor program or pattern (3). The mechanisms involved in the occurrence of LID are complex and have been investigated in numerous studies using animal models and parkinsonian patients (29). The loss of nigrostriatal DA and the chronic administration of L-DOPA, or DA agonists, are two necessary conditions for their appearance (30). The development of LID in human usually requires daily treatment for 3-5 years in idiopathic PD (31), whereas for parkinsonism induced by the toxin MPTP it occurs after only weeks or months of treatment (32). The same applies to the MPTP-lesioned monkey where L-DOPA is usually administered daily for weeks before LID appear $(33,34)$. MPTP-lesioned primates respond to DA therapies as idiopathic PD patients (35, 36) and are currently the best model for studying LID (37).

MPTP-lesioned primates are very useful to test potential antidyskinetic and/or anti-parkinsonian pharmacological agents (37). The primates are rendered parkinsonian and then chronically treated with L-DOPA for several weeks or months until they express stable and well-established LID. Then, acute or chronic effects of compounds are tested when co-administered with LDOPA $(17,18,38,39)$. This model is widely used since it allows rapid testing of new compounds and animals may be used for several studies. This paradigm is useful to find new treatments for advanced parkinsonian patients with already established LID (37).

Another paradigm uses de novo animals rendered parkinsonian with MPTP and then treated with L-DOPA alone or in combination with the agent under investigation (37). This latter paradigm allows the study of specific effects of the test compound on the development of LID and to assess if the effects diminish with long-term use, also called "wearing-off” (40-44). Furthermore, it allows to investigate the post-mortem brains of these monkeys the mechanisms associated with the behaviors and relate it to the specific treatments $(42,44-47)$. This experiment models newly diagnosed parkinsonian patients when L-DOPA treatment is initiated and could be used to test adjunct drugs to L-DOPA to avoid development of LID while having a good anti-parkinsonian effect (37). Docosahexaenoic acid (DHA) and cabergoline were shown to reduce the severity or delay the development of LID in MPTP-lesioned monkey $(41,48)$.

\section{IONOTROPIC GLUTAMATE RECEPTORS AND LEVODOPA-INDUCED DYSKINESIAS}

Ionotropic glutamate receptors mediate fast excitatory neurotransmission, whereas mGlu receptors mediate slower modulatory neurotransmission. iGlu receptors are classified into $N$-methyl-D-aspartate (NMDA), $\alpha$-amino-3-hydroxy-5-methyl4-isoxazolepropionic acid (AMPA), and kainate (KA) receptors (49). An increase in striatal NMDA and AMPA receptor binding levels in PD patients with L-DOPA-induced motor complications (11) and dyskinetic MPTP monkeys was observed (50, 51). Moreover, NMDA and AMPA receptor antagonists block the development of L-DOPA-induced motor complications in 6-OHDA rats (23). The NMDA antagonist, CI-1041 can prevent the development of LID in parkinsonian monkeys (40), and associated brain molecular changes (52). In these monkeys, CI-1041 also prevented the increased of striatal mGlu5 receptor levels (53). Clinical trials show the antidyskinetic profile of amantadine, known to block NMDA receptors $(8,54,55)$. Kynurenic acid antagonizes glycine b site of NMDA receptors, AMPA, and KA receptors (56, 57 ) and inhibits glutamate release (58). RO 61-8048, an inhibitor of kynurenine hydroxylase activity, can increase kynurenic acid levels (59); it acutely reduced dyskinesias in MPTP monkeys with LID (60) and reduced their development in de novo treated MPTP monkeys (61). Abundant recent literature focused on the role of NMDA and AMPA receptor subunits in rodent and nonhuman primate models of PD in LID including the glycine site, NMDA GluN2D subunits, AMPA receptor subunit composition, and NMDA/AMPA receptor ratio $(49,62-66)$. Nevertheless, iGlu receptors can cause significant adverse effects such as cognitive impairment in many patients $(67,68)$.

\section{METABOTROPIC GLUTAMATE RECEPTORS AND LEVODOPA-INDUCED DYSKINESIAS}

Metabotropic glutamate receptors are divided into Group I (mGlu1, 5) coupling to Gq and promoting polyphosphoinositide hydrolysis, Group II (mGlu2, 3) and III (mGlu4, 6, 7, 8) coupling to Gi/Go and inhibiting Forskolin-induced increase in cyclic adenosine monophosphate (cAMP) (69). All mGlu receptors are present in the brain basal ganglia except mGlu6 receptor found primarily in the retina (70). The majority (>90\%) of Group I mGlu receptor, including mGlu5, are located postsynaptically on the perisynaptic annulus of dendritic spines (71). Presynaptically localized Group II and Group III mGlu receptors are thought to represent the classical inhibitory autoreceptor mechanism suppressing excess glutamate release from presynaptic terminals (72). 
The prototypal mGlu5 receptor antagonist, 2-methyl-6(phenylethynyl)pyridine (MPEP) and a more selective analog 3-[(2-methyl-1,3-thiazol-4-yl)ethynyl]pyridine (MTEP) (73) improve motor performance (74) and show antidyskinetic activity in 6-OHDA rats $(75,76)$, but not the other Group I mGlu receptor, such as mGlul receptor drugs $(77,78)$. mGlu5 receptor levels were increased in the putamen of dyskinetic compared to non-dyskinetic MPTP monkeys (42) and parkinsonian patients with motor complications (LID or wearing-off) compared to those without motor complications (53). MPEP and MTEP were shown to have antidyskinetic activity in MPTP monkeys (17) and the mGlu5 receptor antagonist mavoglurant (AFQ056) in MPTP monkeys (18) and humans (19). We reported that development of LID over a month of treatment were lower by overall $\sim 70 \%$ with addition of MPEP to the L-DOPA treatment in de novo MPTP monkeys (44) and this was associated with a normalization of glutamate (46) and DA neurotransmission (47). Similarly, chronic administration of fenobam to drug-naïve monkeys attenuated the development of dyskinesia without compromising the anti-parkinsonian effect of L-DOPA (43).

Group II mGlu receptor agonists have proven effective in animal models of PD (79). A decrease in mGlu2/3 receptor density in dyskinetic compared to non-dyskinetic MPTP-lesioned monkeys was observed (46). In post-mortem brains of parkinsonian patients, changes in mGlu2/3 receptors were only observed in relation to wearing-off (80).

Recently, agonists of Group III receptors have shown robust efficacy in rodent models of $\mathrm{PD}(70)$. mGlu4 receptor agonists reduce $\gamma$-aminobutyric acid (GABA)ergic transmission at striatopallidal synapse that is overactive in PD $(81,82)$. In 6-OHDA-lesioned rats, a combined treatment with $\mathrm{L}$-DOPA and the $\mathrm{mGlu} 4$ receptor agonist Lu AF21934 reduced the effective dose of L-DOPA and minimizing the development of LID (83).

Metabotropic glutamate 8 receptor is expressed at lower levels than mGlu4 and mGlu7 receptors but widely distributed in the brain; mGlu7 receptor has low affinity for glutamate only becoming active when glutamate levels are high thus serving as a brake for glutamate overstimulation (70). AMN082, an mGlu7 receptor agonist, was shown to reverse motor dysfunction associated with reduced DA activity in rodent models (84). However, the contribution of mGlu7 and mGlu8 receptors in LID is not yet reported.

\section{DISCUSSION}

Denervation-induced supersensitivity of DA receptors is generally recognized as a plausible mechanism of LID. Post-mortem studies have shown that DA receptors, particularly D2 subtype, are increased in the striatum of parkinsonian patients (85-87) as well as D1 and D2 receptors in MPTP monkeys $(33,34,88,89)$. However, treatment with L-DOPA can reverse this increase in humans $(85,87)$ and monkeys $(34,88,90)$. LID are clearly more complex than hypersensitivity due to a simple increase in the density of striatal DA receptors (30), hence changes are sought in signaling pathways activated by DA receptors. Various adjunct drugs that can modulate basal ganglia dopaminergic neurotransmission have been shown to treat LID $(13,67,91-94)$. Glutamate receptors are reported to interact with numerous neurotransmitters and neuromodulators implicated in the development of LID including dopaminergic neurotransmission $(22,47)$. Hence, close interactions are described between mGlu5 and NMDA receptors, mGlu5 with D2 receptors, and adenosine A2A receptors (39, 46, 47, 95, 96). Figure 1 shows interactions of striatal DA, adenosine, glutamate and opioids in GABAergic neurons and possible sequence of events leading to LID.

Dopamine receptors are associated with regulation of CAMPprotein kinase A (PKA) through G-protein mediated signaling (97). Downstream from PKA, DA, and cAMP-regulated phosphoprotein with molecular weight 32 (DARPP-32) has important functions in regulating DA receptor signaling and its integration with other signaling modalities (98). Extracellular-signalregulated-kinase (ERK) is also an important mediator of cAMP signaling involved in responses to DA drugs and might be involved in the development of LID (99-101). Rats with abnormal involuntary movements have abnormally high levels of striatal phospho[Thr34]-DARPP-32 (102). DA receptors also exert their effect through protein kinase B (Akt) and glycogen synthase kinase-3 (GSK3) signaling (97) that might serve to integrate signaling of different receptors such as glutamate. Akt can phosphorylate GSK3 $\beta$ at Ser9 [pGSK3 $\beta$ (Ser9)] and inactivate it (103). GSK3 is a juncture of at least three pathways, mitogen-activated protein kinase (MAPK) (104), phosphoinositide 3-kinase (PI3K) (105), and wingless/integrated-signaling (Wnt) (106). Prolonged stimulation of D2 DA receptors in rodents leads to specific dephosphorylation/inactivation of striatal Akt on Thr308 residue [pAkt(Thr308)], Ser473 [pAkt(Ser473)], remaining unaffected (107). Another downstream protein is mammalian target of rapamycin (mTor) recently reported to be implicated in LID (108).

D1 receptor supersensitive response was shown to result from a switch from normal activation of the PKA cascade to aberrant activation of ERK1/2-MAP kinase in lesioned striata and is suggested to underlie LID (109). Interestingly, in a chronic de novo treatment with non-human primates, we observed increases in both striatal pERK1/ERK1 and pERK2/ERK2 ratios of L-DOPA-treated MPTP monkeys whereas MPEP prevented this increase (47). Moreover, there were positive correlations between mean dyskinetic scores and striatal pERK1/ERK1 and pERK2/ERK2 ratios (47). These results suggest that antagonists of mGlu5 receptor can potentially inhibit the excessive striatal activation of nuclear signaling pathways and gene expression that is produced by L-DOPA, which might be related to the interaction with DA receptors.

An association between Akt1 gene and PD was also shown (110). In post-mortem substantia nigra, a large reduction of pAkt(Thr308) and pAkt(Ser473) in PD patients was observed compared to controls (111). L-DOPA-treated MPTP monkeys with LID show elevated pAkt(Ser473) and pGSK3 $\beta$ (Ser9) whereas MPTP monkeys treated with L-DOPA + cabergoline with no LID have lower values (112). In MPTP-lesioned monkeys treated with L-DOPA + CI-1041 that did not develop LID, changes in Akt and GSK3 were modest suggesting implication of other pathways, such as ERK. As in the substantia nigra of parkinsonian patients (111), we observe decreases of striatal pAkt with the MPTP lesion in monkeys (112) whereas in 6-OHDA rats, the lesion did not change or increased phosphorylation of Akt (Ser473 and Thr308) (113). In 6-OHDA rats, pGSK3 $\alpha$ and pGSK3 $\beta$ were also unchanged or increased with the lesion (113) while we 


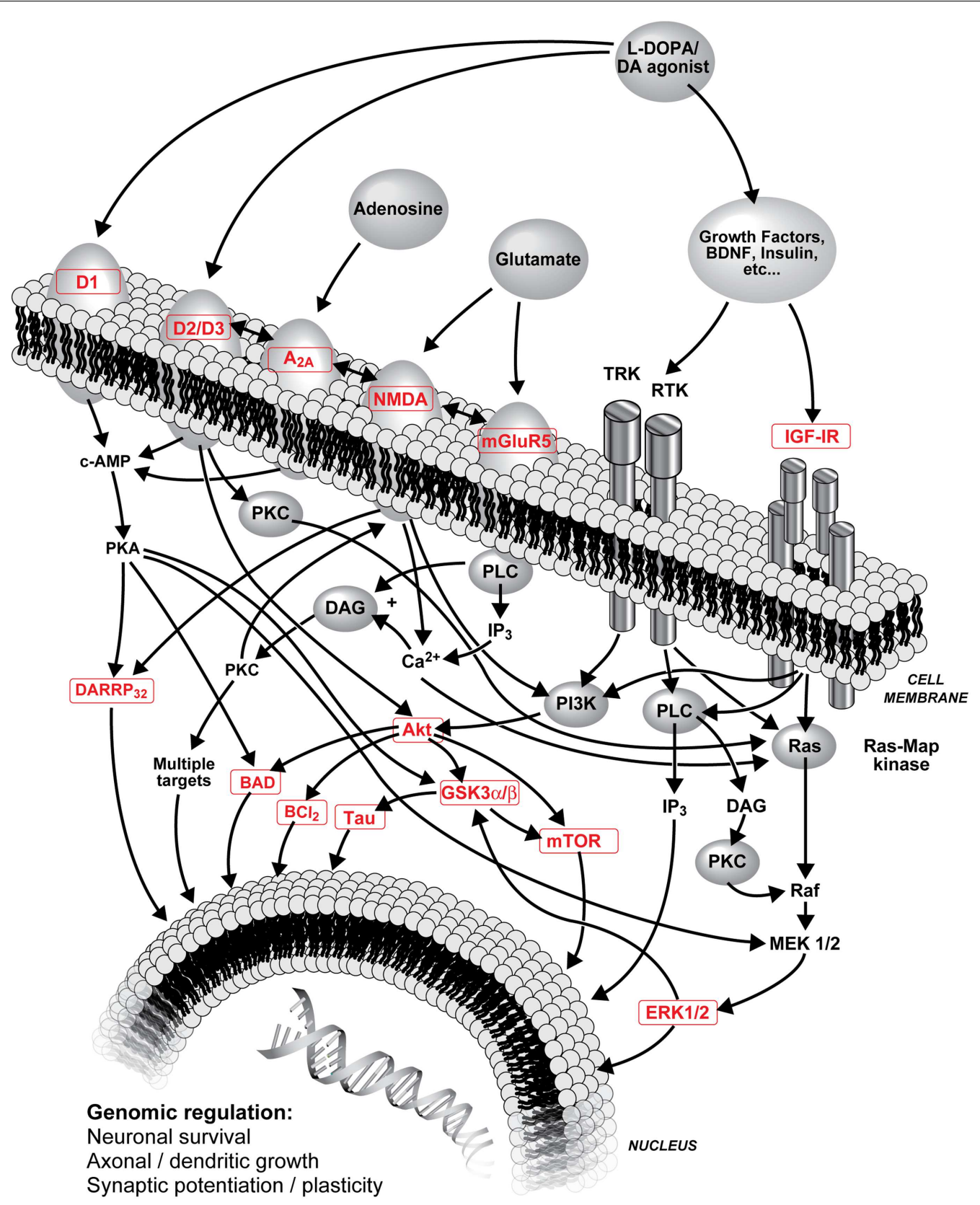

FIGURE 1 | Schematic representation of L-DOPA (metabolized into DA) and DA agonist treatments on striatal DA neurotransmission, interactions of striatal DA, adenosine, glutamate, and opioids in GABAergic neurons and possible sequence of events leading to LID Numerous interactions are known and are not all included; the focus of this figure is on PI3K and MAPK pathways. $A_{2 A}$, adenosine A2A receptor; $A$ kt, protein kinase $\mathrm{B}$; $\mathrm{BAD}, \mathrm{Bcl}$-2-associated death promoter; $\mathrm{Bcl}-2$, B-cell lymphoma 2; $\mathrm{Ca}^{2+}$, calcium ion; cAMP, cyclic adenosine monophosphate; D1/D2/D3, D1/D2/D3 DA receptor; DA, dopamine; DARPP-32, DA and cAMP-regulated phosphoprotein with molecular weight 32; DAG, diacylglycerol; ERK, extracellular-signal-regulated kinase; GSK3, glycogen synthase kinase-3; IGF-IR, type 1 insulin-like growth factor receptor; IP $\mathrm{P}_{3}$, inositol 1,4,5-trisphosphate; L-DOPA, levodopa (L-3,4-dihydroxyphenylalanine); MEK, mitogen-activated protein kinase; mGlu5, metabotropic glutamate type 5 receptor; mTor, mammalian target of rapamycin; NMDA,

$\mathrm{N}$-methyl-d-aspartate receptor; PI3K, phosphoinositide 3-kinase; PKA, protein kinase A; PKC, protein kinase C; PLC, phospholipase C; Ras, proto-oncogene protein p21; Raf, proto-oncogene serine/threonine-protein kinase; RTK, receptor tyrosine kinases; Tau, microtubule-associated protein tau; TRK, tropomyosin receptor kinase. observed no change or decreases in MPTP monkeys (112). However, both in MPTP-lesioned monkeys (112) and in 6-OHDA rats (113), L-DOPA increased pAkt and pGSK3. Moreover, increase in
pAkt(Ser473)/Akt and pGSK3 $\beta$ (Ser9)/GSK3 $\beta$ ratios was observed in the L-DOPA-treated MPTP group, this was prevented with the addition of MPEP and positive correlations were observed between 
these levels and mean dyskinesia scores (47). This supports a possible involvement of Akt/GSK3 $\beta$ in the mechanisms associated with the development of LID. MPEP might prevent changes in this kinase pathway associated with L-DOPA and could provide new avenues to probe potential novel targets to treat LID.

This mini review focused on glutamate neurotransmission in LID and presented some of its interaction with other neurotransmitter systems showing the complexity of this motor complication and its treatment. Indeed, altered dopaminergic and non-dopaminergic neurotransmission, including also serotonergic, adenosine, cannabinoid, opioid, GABAergic, adrenergic, histaminergic, and cholinergic systems are observed in $\operatorname{LID}(12,51)$. For example, serotoninergic dysfunctions in LID are well documented $(114,115)$ and serotonin neurotransmission can interact with iGlu (116-118) and mGlu receptors (119).

\section{CONCLUSION}

Nigrostriatal denervation in PD leads to increased glutamatergic transmission in the basal ganglia; increased glutamate neurotransmission is also observed in LID. These observations suggest that glutamate receptor stimulation is involved in the pathogenesis of L-DOPA-induced motor complications in PD and glutamate receptor subtypes, such as mGlu5 and NMDA receptors, are potential selective targets for treatment of these adverse effects. Recent studies point to changes in activation of DA receptor signaling in LID rather than changes in DA receptor density. Post-mortem brains of dyskinetic MPTP-lesioned monkeys and PD patients treated with anti-glutamatergic drugs and inhibiting LID show multiple brain molecular changes suggesting various receptors interactions. Thus, ionotropic and metabotropic glutamate receptors represent interesting targets to reduce and prevent LID as well as to prevent associated molecular changes beyond their specific receptor target.

\section{ACKNOWLEDGMENTS}

This work was supported by a grant from the Canadian Institutes of Health Research to Thérèse Di Paolo. Nicolas Morin held a professional health care studentship from the Fonds de la Recherche en Santé du Québec.

\section{REFERENCES}

1. Siderowf A, Stern M. Update on Parkinson disease. Ann Intern Med (2003) 138:651-8. doi:10.7326/0003-4819-138-8-200304150-00013

2. Toulouse A, Sullivan AM. Progress in Parkinson's disease-where do we stand? Prog Neurobiol (2008) 85:376-92. doi:10.1016/j.pneurobio.2008.05.003

3. Olanow CW, Stern MB, Sethi K. The scientific and clinical basis for the treatment of Parkinson disease (2009). Neurology (2009) 72:S1-136. doi:10.1212/ WNL.0b013e3181a1d44c

4. Mercuri NB, Bernardi G. The 'magic' of L-DOPA: why is it the gold standard Parkinson's disease therapy? Trends Pharmacol Sci (2005) 26:341-4. doi:10.1016/j.tips.2005.05.002

5. Olanow CW, Koller WC. An algorithm (decision tree) for the management of Parkinson's disease: treatment guidelines. American Academy of Neurology. Neurology (1998) 50:S1-57.

6. Fabbrini G, Brotchie JM, Grandas F, Nomoto M, Goetz CG. Levodopainduced dyskinesias. Mov Disord (2007) 22:1379-1389;quiz1523. doi:10.1002/ mds. 21475

7. Fahn S, Oakes D, Shoulson I, Kieburtz K, Rudolph A, Lang A, et al. Levodopa and the progression of Parkinson's disease. N Engl J Med (2004) 351:2498-508. doi:10.1056/NEJMoa033447
8. Meissner WG, Frasier M, Gasser T, Goetz CG, Lozano A, Piccini P, et al. Priorities in Parkinson's disease research. Nat Rev Drug Discov (2011) 10:377-93. doi: $10.1038 / \mathrm{nrd} 3430$

9. Klockgether T, Turski L. Toward an understanding of the role of glutamate in experimental parkinsonism: agonist-sensitive sites in the basal ganglia. Ann Neurol (1993) 34:585-93. doi:10.1002/ana.410340413

10. Chase TN, Oh JD. Striatal mechanisms and pathogenesis of parkinsonian signs and motor complications. Ann Neurol (2000) 47:S122-9.

11. Calon F, Rajput AH, Hornykiewicz O, Bedard PJ, Di Paolo T. Levodopa-induced motor complications are associated with alterations of glutamate receptors in Parkinson's disease. Neurobiol Dis (2003) 14:404-16. doi:10.1016/j.nbd.2003. 07.003

12. Blandini F, Armentero MT. New pharmacological avenues for the treatment of L-DOPA-induced dyskinesias in Parkinson's disease: targeting glutamate and adenosine receptors. Expert Opin Investig Drugs (2012) 21:153-68. doi:10.1517/13543784.2012.651457

13. Brotchie JM. Adjuncts to dopamine replacement: a pragmatic approach to reducing the problem of dyskinesia in Parkinson's disease. Mov Disord (1998) 13:871-6. doi:10.1002/mds.870130603

14. Johnson KA, Conn PJ, Niswender CM. Glutamate receptors as therapeutic targets for Parkinson's disease. CNS Neurol Disord Drug Targets (2009) 8:475-91. doi:10.2174/187152709789824606

15. Conn PJ, Battaglia G, Marino MJ, Nicoletti F. Metabotropic glutamate receptors in the basal ganglia motor circuit. Nat Rev Neurosci (2005) 6:787-98. doi:10.1038/nrn1763

16. Johnston TH, Fox SH, Mcildowie MJ, Piggott MJ, Brotchie JM. Reduction of L-DOPA-induced dyskinesia by the selective metabotropic glutamate receptor 5 antagonist 3-[(2-methyl-1,3-thiazol-4-yl)ethynyl]pyridine in the 1-methyl-4-phenyl-1,2,3,6-tetrahydropyridine-lesioned macaque model of Parkinson's disease. J Pharmacol Exp Ther (2010) 333:865-73. doi:10.1124/jpet. 110.166629

17. Morin N, Gregoire L, Gomez-Mancilla B, Gasparini F, Di Paolo T. Effect of the metabotropic glutamate receptor type 5 antagonists MPEP and MTEP in parkinsonian monkeys. Neuropharmacology (2010) 58:981-6. doi:10.1016/j. neuropharm.2009.12.024

18. Grégoire L, Morin N, Ouattara B, Gasparini F, Bilbe G, Johns D, et al. The acute antiparkinsonian and antidyskinetic effect of AFQ056, a novel metabotropic glutamate receptor type 5 antagonist, in L-DOPA-treated parkinsonian monkeys. Parkinsonism Relat Disord (2011) 17:270-6. doi:10.1016/j.parkreldis. 2011.01.008

19. Berg D, Godau J, Trenkwalder C, Eggert K, Csoti I, Storch A, et al. AFQ056 treatment of levodopa-induced dyskinesias: results of 2 randomized controlled trials. Mov Disord (2011) 26:1243-50. doi:10.1002/mds.23616

20. Stocchi F, Rascol O, Destee A, Hattori N, Hauser RA, Lang AE, et al. AFQ056 in Parkinson patients with levodopa-induced dyskinesia: 13-week, randomized, dose-finding study. Mov Disord (2013) 28:1838-46. doi:10.1002/mds.25561

21. Gasparini F, Di Paolo T, Gomez-Mancilla B. Metabotropic glutamate receptors for Parkinson's disease therapy. Parkinsons Dis (2013) 2013:196028. doi:10.1155/2013/196028

22. Samadi P, Rouillard C, Bedard PJ, Di Paolo T. Functional neurochemistry of the basal ganglia. Handb Clin Neurol (2007) 83:19-66. doi:10.1016/S00729752(07)83002-8

23. Marin C, Jimenez A, Bonastre M, Chase TN, Tolosa E. Non-NMDA receptormediated mechanisms are involved in levodopa-induced motor response alterations in parkinsonian rats. Synapse (2000) 36:267-74. doi:10.1002/(SICI) 1098-2396(20000615)36:4<267::AID-SYN3>3.0.CO;2-Y

24. Dekundy A, Lundblad M, Danysz W, Cenci MA. Modulation of L-DOPAinduced abnormal involuntary movements by clinically tested compounds: further validation of the rat dyskinesia model. Behav Brain Res (2007) 179:76-89. doi:10.1016/j.bbr.2007.01.013

25. Robelet S, Melon C, Guillet B, Salin P, Kerkerian-Le Goff L. Chronic L-DOPA treatment increases extracellular glutamate levels and GLT1 expression in the basal ganglia in a rat model of Parkinson's disease. Eur J Neurosci (2004) 20:1255-66. doi:10.1111/j.1460-9568.2004.03591.x

26. Oueslati A, Sgambato-Faure V, Melon C, Kachidian P, Gubellini P, Amri M, et al. High-frequency stimulation of the subthalamic nucleus potentiates L-DOPAinduced neurochemical changes in the striatum in a rat model of Parkinson's disease. J Neurosci (2007) 27:2377-86. doi:10.1523/JNEUROSCI.2949-06.2007 
27. Braz CA, Borges V, Ferraz HB. Effect of riluzole on dyskinesia and duration of the on state in Parkinson disease patients: a double-blind, placebo-controlled pilot study. Clin Neuropharmacol (2004) 27:25-9. doi:10.1097/00002826200401000-00008

28. Bara-Jimenez W, Dimitrova TD, Sherzai A, Aksu M, Chase TN. Glutamate release inhibition ineffective in levodopa-induced motor complications. Mov Disord (2006) 21:1380-3. doi:10.1002/mds.20976

29. Iravani MM, Jenner P. Mechanisms underlying the onset and expression of levodopa-induced dyskinesia and their pharmacological manipulation. J Neural Transm Suppl (2011) 118:1661-90. doi:10.1007/s00702-011-0698-2

30. Jenner P. Molecular mechanisms of L-DOPA-induced dyskinesia. Nat Rev Neurosci (2008) 9:665-77. doi:10.1038/nrn2471

31. Klawans HL, Goetz C, Nausieda PA, Weiner WJ. Levodopa-induced dopamine receptor hypersensitivity. Trans Am Neurol Assoc (1977) 102:80-3.

32. Ballard PA, Tetrud JW, Langston JW. Permanent human parkinsonism due to 1-methyl-4-phenyl-1,2,3,6-tetrahydropyridine (MPTP): seven cases. Neurology (1985) 35:949-56. doi:10.1212/WNL.35.7.949

33. Bedard PJ, Di Paolo T, Falardeau P, Boucher R. Chronic treatment with LDOPA, but not bromocriptine induces dyskinesia in MPTP-parkinsonian monkeys. Correlation with [3H]spiperone binding. Brain Res (1986) 379:294-9. doi:10.1016/0006-8993(86)90783-3

34. Falardeau P, Bouchard S, Bedard PJ, Boucher R, Di Paolo T. Behavioral and biochemical effect of chronic treatment with D-1 and/or D-2 dopamine agonists in MPTP monkeys. Eur J Pharmacol (1988) 150:59-66. doi:10.1016/00142999(88)90750-9

35. Jenner P. The contribution of the MPTP-treated primate model to the development of new treatment strategies for Parkinson's disease. Parkinsonism Relat Disord (2003) 9:131-7. doi:10.1016/S1353-8020(02)00115-3

36. Jenner P. The MPTP-treated primate as a model of motor complications in PD: primate model of motor complications. Neurology (2003) 61:S4-11. doi:10.1212/WNL.61.6_suppl_3.S4

37. Morin N, Jourdain VA, Di Paolo T. Modeling dyskinesia in animal models of Parkinson disease. Exp Neurol (2014) 256:105-16. doi:10.1016/j.expneurol. 2013.01.024

38. Bezard E, Hill MP, Crossman AR, Brotchie JM, Michel A, Grimee R, et al. Levetiracetam improves choreic levodopa-induced dyskinesia in the MPTP-treated macaque. Eur J Pharmacol (2004) 485:159-64. doi:10.1016/j.ejphar.2003.11. 065

39. Grégoire L, Samadi P, Graham J, Bedard PJ, Bartoszyk GD, Di Paolo T. Low doses of sarizotan reduce dyskinesias and maintain antiparkinsonian efficacy of LDOPA in parkinsonian monkeys. Parkinsonism Relat Disord (2009) 15:445-52. doi:10.1016/j.parkreldis.2008.11.001

40. Hadj Tahar A, Gregoire L, Darre A, Belanger N, Meltzer L, Bedard PJ. Effect of a selective glutamate antagonist on L-DOPA-induced dyskinesias in drugnaive parkinsonian monkeys. Neurobiol Dis (2004) 15:171-6. doi:10.1016/j. nbd.2003.10.007

41. Samadi P, Gregoire L, Rouillard C, Bedard PJ, Di Paolo T, Levesque D Docosahexaenoic acid reduces levodopa-induced dyskinesias in 1-methyl4-phenyl-1,2,3,6-tetrahydropyridine monkeys. Ann Neurol (2006) 59:282-8. doi:10.1002/ana.20738

42. Samadi P, Gregoire L, Morissette M, Calon F, Hadj Tahar A, Dridi M, et al. mGluR5 metabotropic glutamate receptors and dyskinesias in MPTP monkeys. Neurobiol Aging (2008) 29:1040-51. doi:10.1016/j.neurobiolaging. 2007.02.005

43. Rylander D, Iderberg H, Li Q, Dekundy A, Zhang J, Li H, et al. A mGluR5 antagonist under clinical development improves L-DOPA-induced dyskinesia in parkinsonian rats and monkeys. Neurobiol Dis (2010) 39:352-61. doi:10.1016/j.nbd.2010.05.001

44. Morin N, Grégoire L, Morissette M, Desrayaud S, Gomez-Mancilla B, Gasparini $\mathrm{F}$, et al. MPEP, an mGlu5 receptor antagonist, reduces the development of L-DOPA-induced motor complications in de novo parkinsonian monkeys: biochemical correlates. Neuropharmacology (2013) 66:355-64. doi:10.1016/j.neuropharm.2012.07.036

45. Ouattara B, Gasparini F, Morissette M, Gregoire L, Samadi P, Gomez-Mancilla B, et al. Effect of L-DOPA on metabotropic glutamate receptor 5 in the brain of parkinsonian monkeys. J Neurochem (2010) 113:715-24. doi:10.1111/j.14714159.2010.06635.x

46. Morin N, Morissette M, Gregoire L, Gomez-Mancilla B, Gasparini F, Di Paolo T. Chronic treatment with MPEP, an mGlu5 receptor antagonist, normalizes basal ganglia glutamate neurotransmission in L-DOPA-treated parkinsonian monkeys. Neuropharmacology (2013) 73:216-31. doi:10.1016/j.neuropharm. 2013.05.028

47. Morin N, Jourdain VA, Morissette M, Gregoire L, Di Paolo T. Long-term treatment with L-DOPA and an mGlu5 receptor antagonist prevents changes in brain basal ganglia dopamine receptors, their associated signaling proteins and neuropeptides in parkinsonian monkeys. Neuropharmacology (2014) 79:688-706. doi:10.1016/j.neuropharm.2014.01.014

48. Belanger N, Gregoire L, Hadj Tahar A, Bedard PJ. Chronic treatment with small doses of cabergoline prevents DOPA-induced dyskinesias in parkinsonian monkeys. Mov Disord (2003) 18:1436-41. doi:10.1002/mds.10589

49. Finlay C, Duty S. Therapeutic potential of targeting glutamate receptors in Parkinson's disease. J Neural Transm (2014). doi:10.1007/s00702-014-1176-4

50. Calon F, Morissette M, Ghribi O, Goulet M, Grondin R, Blanchet PJ, et al. Alteration of glutamate receptors in the striatum of dyskinetic 1-methyl-4phenyl-1,2,3,6-tetrahydropyridine-treated monkeys following dopamine agonist treatment. Prog Neuropsychopharmacol Biol Psychiatry (2002) 26:127-38. doi:10.1016/S0278-5846(01)00237-8

51. Huot P, Johnston TH, Koprich JB, Fox SH, Brotchie JM. The pharmacology of L-DOPA-induced dyskinesia in Parkinson's disease. Pharmacol Rev (2013) 65:171-222. doi:10.1124/pr.111.005678

52. Morissette M, Dridi M, Calon F, Hadj Tahar A, Meltzer LT, Bedard PJ, et al. Prevention of levodopa-induced dyskinesias by a selective NR1A/2B N-methyl$\mathrm{D}$-aspartate receptor antagonist in parkinsonian monkeys: implication of preproenkephalin. Mov Disord (2006) 21:9-17. doi:10.1002/mds.20654

53. Ouattara B, Gregoire L, Morissette M, Gasparini F, Vranesic I, Bilbe G, et al. Metabotropic glutamate receptor type 5 in levodopa-induced motor complications. Neurobiol Aging (2011) 32:1286-95. doi:10.1016/j.neurobiolaging.2009. 07.014

54. Verhagen Metman L, Del Dotto P, Van Den Munckhof P, Fang J, Mouradian MM, Chase TN. Amantadine as treatment for dyskinesias and motor fluctuations in Parkinson's disease. Neurology (1998) 50:1323-6. doi:10.1212/WNL. 50.5.1323

55. Sawada H, Oeda T, Kuno S, Nomoto M, Yamamoto K, Yamamoto M, et al. Amantadine for dyskinesias in Parkinson's disease: a randomized controlled trial. PLoS One (2010) 5:e15298. doi:10.1371/journal.pone.0015298

56. Stone TW. Development and therapeutic potential of kynurenic acid and kynurenine derivatives for neuroprotection. Trends Pharmacol Sci (2000) 21:149-54. doi:10.1016/S0165-6147(00)01451-6

57. Schwarcz R, Pellicciari R. Manipulation of brain kynurenines: glial targets, neuronal effects, and clinical opportunities. J Pharmacol Exp Ther (2002) 303:1-10. doi:10.1124/jpet.102.034439

58. Nemeth H, Toldi J, Vecsei L. Kynurenines, Parkinson's disease and other neurodegenerative disorders: preclinical and clinical studies. J Neural Transm Suppl (2006) 70:285-304. doi:10.1007/978-3-211-45295-0_45

59. Stone TW. Kynurenines in the CNS: from endogenous obscurity to therapeutic importance. Prog Neurobiol (2001) 64:185-218. doi:10.1016/S0301-0082(00) 00032-0

60. Samadi P, Gregoire L, Rassoulpour A, Guidetti P, Izzo E, Schwarcz R, et al. Effect of kynurenine 3-hydroxylase inhibition on the dyskinetic and antiparkinsonian responses to levodopa in parkinsonian monkeys. Mov Disord (2005) 20:792-802. doi:10.1002/mds.20596

61. Grégoire L, Rassoulpour A, Guidetti P, Samadi P, Bedard PJ, Izzo E, et al. Prolonged kynurenine 3-hydroxylase inhibition reduces development of levodopainduced dyskinesias in parkinsonian monkeys. Behav Brain Res (2008) 186:161-7. doi:10.1016/j.bbr.2007.08.007

62. Kobylecki C, Cenci MA, Crossman AR, Ravenscroft P. Calcium-permeable AMPA receptors are involved in the induction and expression of L-DOPAinduced dyskinesia in Parkinson's disease. J Neurochem (2010) 114:499-511. doi:10.1111/j.1471-4159.2010.06776.x

63. Errico F, Bonito-Oliva A, Bagetta V, Vitucci D, Romano R, Zianni E, et al. Higher free D-aspartate and N-methyl-D-aspartate levels prevent striatal depotentiation and anticipate L-DOPA-induced dyskinesia. Exp Neurol (2011) 232:240-50. doi:10.1016/j.expneurol.2011.09.013

64. Bagetta V, Sgobio C, Pendolino V, Del Papa G, Tozzi A, Ghiglieri V, et al. Rebalance of striatal NMDA/AMPA receptor ratio underlies the reduced emergence of dyskinesia during D2-like dopamine agonist treatment in experimental Parkinson's disease. J Neurosci (2012) 32:17921-31. doi:10.1523/JNEUROSCI. 2664-12.2012 
65. Heresco-Levy U, Shoham S, Javitt DC. Glycine site agonists of the N-methylD-aspartate receptor and Parkinson's disease: a hypothesis. Mov Disord (2013) 28:419-24. doi:10.1002/mds.25306

66. Zhang X, Feng ZJ, Chergui K. GluN2D-containing NMDA receptors inhibit neurotransmission in the mouse striatum through a cholinergic mechanism: implication for Parkinson's disease. J Neurochem (2014) 129:581-90. doi:10.1111/jnc. 12658

67. Stocchi F, Tagliati M, Olanow CW. Treatment of levodopa-induced motor complications. Mov Disord (2008) 23(Suppl 3):S599-612. doi:10.1002/mds.22052

68. Stayte S, Vissel B. Advances in non-dopaminergic treatments for Parkinson's disease. Front Neurosci (2014) 8:113. doi:10.3389/fnins.2014.00113

69. Conn PJ, Pin JP. Pharmacology and functions of metabotropic glutamate receptors. Annu Rev Pharmacol Toxicol (1997) 37:205-37. doi:10.1146/annurev. pharmtox.37.1.205

70. Niswender CM, Conn PJ. Metabotropic glutamate receptors: physiology, pharmacology, and disease. Annu Rev Pharmacol Toxicol (2010) 50:295-322. doi:10.1146/annurev.pharmtox.011008.145533

71. Lujan R, Roberts JD, Shigemoto R, Ohishi H, Somogyi P. Differential plasma membrane distribution of metabotropic glutamate receptors mGluR1 alpha, mGluR2 and mGluR5, relative to neurotransmitter release sites. J Chem Neuroanat (1997) 13:219-41. doi:10.1016/S0891-0618(97)00051-3

72. Schoepp DD. Unveiling the functions of presynaptic metabotropic glutamate receptors in the central nervous system. J Pharmacol Exp Ther (2001) 299:12-20.

73. Carroll FI. Antagonists at metabotropic glutamate receptor subtype 5: structure activity relationships and therapeutic potential for addiction. Ann NY Acad Sci (2008) 1141:221-32. doi:10.1196/annals.1441.015

74. Breysse N, Baunez C, Spooren W, Gasparini F, Amalric M. Chronic but not acute treatment with a metabotropic glutamate 5 receptor antagonist reverses the akinetic deficits in a rat model of parkinsonism. J Neurosci (2002) 22:5669-78.

75. Mela F, Marti M, Dekundy A, Danysz W, Morari M, Cenci MA. Antagonism of metabotropic glutamate receptor type 5 attenuates L-DOPA-induced dyskinesia and its molecular and neurochemical correlates in a rat model of Parkinson's disease. J Neurochem (2007) 101:483-97. doi:10.1111/j.1471-4159.2007. 04456.x

76. Levandis G, Bazzini E, Armentero MT, Nappi G, Blandini F. Systemic administration of an mGluR5 antagonist, but not unilateral subthalamic lesion, counteracts L-DOPA-induced dyskinesias in a rodent model of Parkinson's disease. Neurobiol Dis (2008) 29:161-8. doi:10.1016/j.nbd.2007.08.011

77. Dekundy A, Pietraszek M, Schaefer D, Cenci MA, Danysz W. Effects of Group I metabotropic glutamate receptors blockade in experimental models of Parkinson's disease. Brain Res Bull (2006) 69:318-26. doi:10.1016/j.brainresbull.2005. 12.009

78. Rylander D, Recchia A, Mela F, Dekundy A, Danysz W, Cenci MA. Pharmacological modulation of glutamate transmission in a rat model of L-DOPAinduced dyskinesia: effects on motor behavior and striatal nuclear signaling. J Pharmacol Exp Ther (2009) 330:227-35. doi:10.1124/jpet.108.150425

79. Pisani A, Bonsi P, Centonze D, Gubellini P, Bernardi G, Calabresi P. Targeting striatal cholinergic interneurons in Parkinson's disease: focus on metabotropic glutamate receptors. Neuropharmacology (2003) 45:45-56. doi:10.1016/S00283908(03)00137-0

80. Samadi P, Rajput A, Calon F, Gregoire L, Hornykiewicz O, Rajput AH, et al. Metabotropic glutamate receptor II in the brains of parkinsonian patients. J Neuropathol Exp Neurol (2009) 68:374-82. doi:10.1097/NEN. 0b013e31819cabe4

81. Matsui T, Kita H. Activation of Group III metabotropic glutamate receptors presynaptically reduces both GABAergic and glutamatergic transmission in the rat globus pallidus. Neuroscience (2003) 122:727-37. doi:10.1016/j. neuroscience.2003.08.032

82. Macinnes N, Duty S. Group III metabotropic glutamate receptors act as heteroreceptors modulating evoked GABA release in the globus pallidus in vivo. Eur J Pharmacol (2008) 580:95-9. doi:10.1016/j.ejphar.2007.10.030

83. Bennouar KE, Uberti MA, Melon C, Bacolod MD, Jimenez HN, Cajina M, et al. Synergy between L-DOPA and a novel positive allosteric modulator of metabotropic glutamate receptor 4: implications for Parkinson's disease treatment and dyskinesia. Neuropharmacology (2013) 66:158-69. doi:10.1016/j. neuropharm.2012.03.022
84. Greco B, Lopez S, Van Der Putten H, Flor PJ, Amalric M. Metabotropic glutamate 7 receptor subtype modulates motor symptoms in rodent models of Parkinson's disease. J Pharmacol Exp Ther (2010) 332:1064-71. doi:10.1124/ jpet.109.162115

85. Lee T, Seeman P, Rajput A, Farley IJ, Hornykiewicz O. Receptor basis for dopaminergic supersensitivity in Parkinson's disease. Nature (1978) 273:59-61. doi: $10.1038 / 273059 \mathrm{a} 0$

86. Bokobza B, Ruberg M, Scatton B, Javoy-Agid F, Agid Y. [3H] spiperone binding, dopamine and HVA concentrations in Parkinson's disease and supranuclear palsy. Eur J Pharmacol (1984) 99:167-75. doi:10.1016/0014-2999(84)90238-3

87. Guttman M, Seeman P, Reynolds GP, Riederer P, Jellinger K, Tourtellotte WW. Dopamine D2 receptor density remains constant in treated Parkinson's disease. Ann Neurol (1986) 19:487-92. doi:10.1002/ana.410190510

88. Gagnon C, Bedard PJ, Di Paolo T. Effect of chronic treatment of MPTP monkeys with dopamine D-1 and/or D-2 receptor agonists. Eur J Pharmacol (1990) 178:115-20. doi:10.1016/0014-2999(90)94802-5

89. Graham WC, Sambrook MA, Crossman AR. Differential effect of chronic dopaminergic treatment on dopamine D1 and D2 receptors in the monkey brain in MPTP-induced parkinsonism. Brain Res (1993) 602:290-303. doi:10.1016/0006-8993(93)90694-I

90. Berretta S, Parthasarathy HB, Graybiel AM. Local release of GABAergic inhibition in the motor cortex induces immediate-early gene expression in indirect pathway neurons of the striatum. J Neurosci (1997) 17:4752-63.

91. Blanchet PJ, Konitsiotis S, Whittemore ER, Zhou ZL, Woodward RM, Chase TN. Differing effects of N-methyl-D-aspartate receptor subtype selective antagonists on dyskinesias in levodopa-treated 1-methyl-4-phenyltetrahydropyridine monkeys. J Pharmacol Exp Ther (1999) 290:1034-40.

92. Grondin R, Bedard PJ, Hadj Tahar A, Gregoire L, Mori A, Kase H. Antiparkinsonian effect of a new selective adenosine A2A receptor antagonist in MPTPtreated monkeys. Neurology (1999) 52:1673-7. doi:10.1212/WNL.52.8.1673

93. Henry B, Fox SH, Crossman AR, Brotchie JM. Mu- and delta-opioid receptor antagonists reduce levodopa-induced dyskinesia in the MPTP-lesioned primate model of Parkinson's disease. Exp Neurol (2001) 171:139-46. doi:10.1006/exnr. 2001.7727

94. Calon F, Di Paolo T. Levodopa response motor complications-GABA receptors and preproenkephalin expression in human brain. Parkinsonism Relat Disord (2002) 8:449-54. doi:10.1016/S1353-8020(02)00029-9

95. Kachroo A, Orlando LR, Grandy DK, Chen JF, Young AB, Schwarzschild MA. Interactions between metabotropic glutamate 5 and adenosine A2A receptors in normal and parkinsonian mice. J Neurosci (2005) 25:10414-9. doi:10.1523/JNEUROSCI.3660-05.2005

96. Fuxe K, Marcellino D, Rivera A, Diaz-Cabiale Z, Filip M, Gago B, et al. Receptorreceptor interactions within receptor mosaics. Impact on neuropsychopharmacology. Brain Res Rev (2008) 58:415-52. doi:10.1016/j.brainresrev.2007.11.007

97. Beaulieu JM, Gainetdinov RR, Caron MG. The Akt-GSK-3 signaling cascade in the actions of dopamine. Trends Pharmacol Sci (2007) 28:166-72. doi:10.1016/j.tips.2007.02.006

98. Greengard P. The neurobiology of slow synaptic transmission. Science (2001) 294:1024-30. doi:10.1126/science.294.5544.1024

99. Valjent E, Pascoli V, Svenningsson P, Paul S, Enslen H, Corvol JC, et al. Regulation of a protein phosphatase cascade allows convergent dopamine and glutamate signals to activate ERK in the striatum. Proc Natl Acad Sci U S A (2005) 102:491-6. doi:10.1073/pnas.0408305102

100. Beaulieu JM, Sotnikova TD, Gainetdinov RR, Caron MG. Paradoxical striatal cellular signaling responses to psychostimulants in hyperactive mice. J Biol Chem (2006) 281:32072-80. doi:10.1074/jbc.M606062200

101. Valjent E, Corvol JC, Trzaskos JM, Girault JA, Herve D. Role of the ERK pathway in psychostimulant-induced locomotor sensitization. BMC Neurosci (2006) 7:20. doi:10.1186/1471-2202-7-20

102. Picconi B, Centonze D, Hakansson K, Bernardi G, Greengard P, Fisone G, et al. Loss of bidirectional striatal synaptic plasticity in L-DOPA-induced dyskinesia. Nat Neurosci (2003) 6:501-6. doi:10.1038/nn1040

103. Chong ZZ, Li F, Maiese K. Activating Akt and the brain's resources to drive cellular survival and prevent inflammatory injury. Histol Histopathol (2005) 20:299-315.

104. Pelech SL, Charest DL. MAP kinase-dependent pathways in cell cycle control. Prog Cell Cycle Res (1995) 1:33-52. doi:10.1007/978-1-4615-1809-9_4 
105. Shaw PC, Davies AF, Lau KF, Garcia-Barcelo M, Waye MM, Lovestone S, et al. Isolation and chromosomal mapping of human glycogen synthase kinase-3 alpha and -3 beta encoding genes. Genome (1998) 41:720-7. doi:10.1139/g98073

106. Salinas PC. Wnt factors in axonal remodelling and synaptogenesis. Biochem Soc Symp (1999) 65:101-9.

107. Beaulieu JM, Sotnikova TD, Marion S, Lefkowitz RJ, Gainetdinov RR, Caron MG. An Akt/beta-arrestin 2/PP2A signaling complex mediates dopaminergic neurotransmission and behavior. Cell (2005) 122:261-73. doi:10.1016/j.cell. 2005.05.012

108. Santini E, Heiman M, Greengard P, Valjent E, Fisone G. Inhibition of mTOR signaling in Parkinson's disease prevents L-DOPA-induced dyskinesia. Sci Signal (2009) 2:ra36. doi:10.1126/scisignal.2000308

109. Gerfen CR. D1 dopamine receptor supersensitivity in the dopamine-depleted striatum animal model of Parkinson's disease. Neuroscientist (2003) 9:455-62. doi: $10.1177 / 1073858403255839$

110. Xiromerisiou G, Hadjigeorgiou GM, Papadimitriou A, Katsarogiannis E, Gourbali V, Singleton AB. Association between AKT1 gene and Parkinson's disease: a protective haplotype. Neurosci Lett (2008) 436:232-4. doi:10.1016/j.neulet. 2008.03.026

111. Malagelada C, Jin ZH, Greene LA. RTP801 is induced in Parkinson's disease and mediates neuron death by inhibiting Akt phosphorylation/activation. J Neurosci (2008) 28:14363-71. doi:10.1523/JNEUROSCI.3928-08.2008

112. Morissette M, Samadi P, Hadj Tahar A, Belanger N, Di Paolo T. Striatal Akt/GSK3 signaling pathway in the development of L-DOPA-induced dyskinesias in MPTP monkeys. Prog Neuropsychopharmacol Biol Psychiatry (2010) 34:446-54. doi:10.1016/j.pnpbp.2009.12.011

113. Bychkov E, Ahmed MR, Dalby KN, Gurevich EV. Dopamine depletion and subsequent treatment with L-DOPA, but not the long-lived dopamine agonist pergolide, enhances activity of the Akt pathway in the rat striatum. JNeurochem (2007) 102:699-711. doi:10.1111/j.1471-4159.2007.04586.x

114. Carta M, Carlsson T, Kirik D, Bjorklund A. Dopamine released from 5-HT terminals is the cause of L-DOPA-induced dyskinesia in parkinsonian rats. Brain (2007) 130:1819-33. doi:10.1093/brain/awm082
115. Rylander D, Parent M, O’Sullivan SS, Dovero S, Lees AJ, Bezard E, et al. Maladaptive plasticity of serotonin axon terminals in levodopa-induced dyskinesia. Ann Neurol (2010) 68:619-28. doi:10.1002/ana.22097

116. Riahi G, Morissette M, Parent M, Di Paolo T. Brain 5-HT(2A) receptors in MPTP monkeys and levodopa-induced dyskinesias. Eur J Neurosci (2011) 33:1823-31. doi:10.1111/j.1460-9568.2011.07675.x

117. Riahi G, Morissette M, Levesque D, Rouillard C, Samadi P, Parent M, et al. Effect of chronic L-DOPA treatment on 5-HT(1A) receptors in parkinsonian monkey brain. Neurochem Int (2012) 61:1160-71. doi:10.1016/j.neuint.2012.08.009

118. Riahi G, Morissette M, Samadi P, Parent M, Di Paolo T. Basal ganglia serotonin $1 \mathrm{~B}$ receptors in parkinsonian monkeys with L-DOPA-induced dyskinesia. Biochem Pharmacol (2013) 86:970-8. doi:10.1016/j.bcp.2013.08.005

119. Morin N, Morissette M, Gregoire L, Di Paolo T. Effect of a chronic treatment with an mGlu5 receptor antagonist on brain serotonin markersin parkinsonian monkeys. Prog Neuropsychopharmacol Biol Psychiatry (2014). doi:10.1016/j.pnpbp.2014.07.006

Conflict of Interest Statement: The authors declare that the research was conducted in the absence of any commercial or financial relationships that could be construed as a potential conflict of interest.

Received: 23 May 2014; paper pending published: 01 July 2014; accepted: 18 July 2014; published online: 05 August 2014.

Citation: Morin N and Di Paolo T (2014) Pharmacological treatments inhibiting levodopa-induced dyskinesias in MPTP-lesioned monkeys: brain glutamate biochemical correlates. Front. Neurol. 5:144. doi: 10.3389/fneur.2014.00144

This article was submitted to Movement Disorders, a section of the journal Frontiers in Neurology.

Copyright (C) 2014 Morin and Di Paolo. This is an open-access article distributed under the terms of the Creative Commons Attribution License (CC BY). The use, distribution or reproduction in other forums is permitted, provided the original author (s) or licensor are credited and that the original publication in this journal is cited, in accordance with accepted academic practice. No use, distribution or reproduction is permitted which does not comply with these terms. 